\title{
KAJIAN PENGOBATAN DAN KEPATUHAN PASIEN MULTIDRUG-RESISTANT TUBERCULOSIS (MDR-TB) DI RSUD A.W SJAHRANIE SAMARINDA
}

\author{
Mega Shinta*, Sabaniah Indjar Gama, Adam M. Ramadhan \\ Laboratorium Penelitian dan Pengembangan FARMAKA TROPIS Fakultas Farmasi \\ Universitas Mulawarman, Samarinda, Kalimantan Timur \\ *email: lovelyshinta17@gmail.com
}

\begin{abstract}
ABSTRAK
Multi Drug Resistant Tuberculosis (MDR-TB) merupakan penyakit yang terinfeksi Mycobacterium tuberculosis yang resistan terhadap dua obat anti-tuberkulosis (OAT) yang paling poten yaitu Isoniazid (INH) dan Rifampisin (RIF). Terjadinya resistan dapat disebabkan pengobatan yang tidak adekuat dan faktor pasien yaitu ketidakpatuhan dalam menjalani pengobatan tuberkulosis. Sehingga penelitian ini bertujuan untuk mengkaji pengobatan MDR-TB dan hubungan kepatuhan responden dalam menjalani pengobatan. Penelitian ini dilakukan dengan cara pengambilan data menggunakan case control secara prospektif. Hasil analisis penelitian ini ditemukan kepatuhan responden dipengaruhi oleh jenis kelamin laki-laki 72,73\% dan 90\% perempuan, sedangkan berdasarkan usia kepatuhan tertinggi yaitu pada rentang usia 20-34 tahun (80\%). Pekerjaan salah satu karakteristik faktor kepatuhan responden dalam pengobatan dimana kepatuhan terbesar yaitu responden yang tidak bekerja sebesar 88,9\%, sedangkan tingkat kepatuhan berdasarkan tempat berobat menunjukkan angka sebesar $80,95 \%$ melalui satelit dan pusat $72,7 \%$. Sebanyak $76,19 \%$ responden MDR-TB tanpa penyakit penyerta dan 81,8\% responden MDR-TB dengan penyakit penyerta patuh dalam pengobatan. Pola pengobatan diberikan sesuai dengan standar OAT yang telah ditetapkan oleh nasional (6 Km-E-Etho-Levo-Z-Cs/ 18 E-EthoLevo-Z-Cs), dimana tingkat kepatuhan terbesar yaitu pada tahap lanjutan $80 \%$, sedangkan pada tahap intensif tingkat kepatuhan sebesar $71,43 \%$. Sehingga secara keseluruhan tingkat kepatuhan responden MDR-TB cukup tinggi dengan hasil 78,12\%.
\end{abstract}

Kata kunci: Kepatuhan, OAT, Multi Drug Resistant Tuberculosis (MDR-TB).

\section{ABSTRACT}

Multi Drug Resistant Tuberculosis (MDR-TB) is caused by an organism of Mycobacterium tuberculosis to at least two most potent anti-tuberculosis drugs (ATD) are isoniazid (INH) and rifampicin $(R I F)$. The occurrence of resistance may be due to inadequate treatment and patient factors, namely non-compliance in the treatment of tuberculosis. Thus, this study intend to examine the treatment of MDR-TB and the relationship of respondents in treatment compliance. This research was conducted by collecting data using the case control prospectively. The results of this research analysis found compliance of respondents were influenced by sex $72.73 \%$ male and $90 \%$ female, while based on the age of the highest compliance is in the age range 20-34 years (80\%). Work one of the characteristics of respondents adherence factor in the treatment where the greatest adherence of respondents who did not work at $88.9 \%$, while the level of compliance by place of treatment showed the number of $80.95 \%$ via satellite and center of $72.7 \%$. As much as $76.19 \%$ of respondents $M D R-T B$ without comorbidities and $81.8 \%$ of respondents MDR-TB with comorbidities are obedient. The patterns of treatment provided in accordance with the standards of OAT set 
by the national (6 Km-E-Etho-Levo-Z-Cs / 18 E-Etho-Levo-Z-Cs), where the level of compliance total of advanced stages of $80 \%$, while at the stage of intensive compliance rate of $71.43 \%$. Accordingly the overall level of compliance of respondents MDR-TB is high enough with the result of $78.12 \%$.

Keywords: Compliance, anti-tuberculosis drugs, Multi Drug Resistant Tuberculosis (MDRTB)

\section{PENDAHULUAN}

Tuberkulosis paru merupakan infeksi yang disebabkan oleh kuman Mycobacterium tuberculosis (kadang-kadang disebabkan oleh M. bovis dan africanum), yang pada umumnya menyerang paru dan sebagian menyerang di luar paru, seperti kelenjar getah bening (kelenjar), kulit, usus atau saluran pencernaan, selaput otak, dan sebagainya. Organisme ini disebut pula sebagai basil tahan asam (WHO, 2011).

Terjadinya resistensi kuman $M$. tuberculosis terhadap OAT merupakan masalah yang ditemui pada pengobatan TB. Resistensi ini merupakan keadaan dimana OAT tidak mampu untuk membunuh kuman M. tuberculosis. Salah satu jenis resistensi tersebut adalah TB Multi Drug Resistant atau resistensi obat ganda. Tuberculosis Multi Drug Resistant (TB MDR) merupakan TB yang disebabkan oleh bakteri TB yang telah resisten terhadap 2 jenis OAT (obat antituberkulosis) yaitu INH dan Rifampisin. Resistensi bakteri TB terhadap OAT telah muncul sejak lama. Resistensi obat pada pasien yang memiliki riwayat pengobatan sebelumnya adalah sebesar 4 kali lipat, sedangkan pada TB MDR sebesar 10 kali lipat atau lebih dibandingkan dengan pasien yang belum pernah melakukan pengobatan (KEMENKES, 2014).

WHO menyatakan 22 negara dengan beban tuberkulosis paru tertinggi di dunia 50\%nya berasal dari negara-negara Afrika dan Asia serta Amerika (Brasil). Hampir semua negara ASEAN masuk dalam kategori 22 negara tersebut, kecuali Singapura dan Malaysia. Dari seluruh kasus tuberkulosis paru di dunia, India menyumbang 30\%, China menyumbang $15 \%$ dan Indonesia 5\%. Laporan WHO pada tahun 2010, mencatat peringkat Indonesia menurun ke posisi lima dengan estimasi jumlah penderita tuberkulosis paru sebesar 430.000 kasus baru per tahun. Lima negara dengan jumlah terbesar kasus insiden pada tahun 2010 adalah India, Cina, Afrika Selatan, Negeria dan Indonesia (WHO, 2011).

Secara nasional menunjukkan perkembangan yang meningkat dalam penemuan kasus dan tingkat kesembuhan, pencapaian di tingkat provinsi masih menunjukkan disparitas antar wilayah. Sebanyak 28 provinsi di Indonesia belum dapat mencapai angka penemuan kasus . Case Detection Rate (CDR) 70\% dan hanya 5 (lima) provinsi menunjukkan pencapaian $70 \%$ CDR dan 85\% kesembuhan. Masalah tuberkulosis paru di Indonesia sangat besar, karena setiap tahunnya kasus baru 250.000 penderita dan sekitar 140.000 kematian terjadi pada setiap tahun yang disebabkan tuberkulosis paru. Walaupun Indonesia telah mencapai kemajuan yang pesat dalam hal peningkatan penemuan kasus tuberkulosis paru menular sebesar 51,6\%, pada saat yang sama. Hasil ini memperlihatkan hanya setengah dari penderita tuberkulosis yang dapat diobati di puskesmas seluruh Indonesia. Penyakit tuberkulosis paru tanpa pengobatan setelah 5 tahun, 50\% dari penderita akan meninggal, 25\% akan sembuh sendiri dengan daya tahan tubuh yang tinggi dan $25 \%$ sebagai kasus kronis yang tetap menular (WHO, 2011).

Panduan Obat antituberkulosis pada pasien TB MDR di Indonesia adalah (Km-EtoLfx-Cs-Z-E/Eto-Lfx-Cs-Z-E). Panduan yang diberikan yaitu $\mathrm{Km}$ (Kanamisin), Eto (Etionamid), Lfx (Levofloksasin), Cs (Sikloserin), Z (Pirazinamid) dan E (Etambutol) (KEMENKES, 2014). 


\section{METODE PENELITIAN}

Metode penelitian ini adalah secara deskriptif, dengan pengambilan data secara prospektif, dimana data untuk hasil penelitian didapatkan dari rekam medik dari setiap pasien Multidrug Resistant Tuberculosis (MDR-TB). Hasil yang didapatkan kemudian dianalisis dan diidentifikasi sehingga diperoleh suatu kesimpulan.

\section{HASIL DAN PEMBAHASAN}

Menurut World Health Organization (WHO, 2011), terdapat sekitar 500.000 kasus Tuberkulosis yang resistan terhadap isoniazid dan rifampisin setiap tahunnya dengan angka kematian sekitar 150.000 dan sekitar 10\% kasus yang baru ditemukan dan diobati. Dalam Rencana The Global Plan to Stop Tuberculosis direncanakan untuk mengobati sekitar 1,6 juta pasien TB MDR di dunia pada tahun 2006 sampai 2015 dimana 60\% dari jumlah pasien tersebut berada di negara-negara dengan beban MDR-TB tinggi (MDR-TB high burden countries), dimana prevalensi MDR-TB di dunia diperkirakan 2-3 kali lipat lebih tinggi dari kasus yang ada.

Angka kejadian MDR-TB yang sedang menjalani pengobatan di Rumah Sakit Abdul Wahab Sjahranie Samarinda terus meningkat sejak tahun 2014. Sebanyak 37 pasien MDRTB yang menjalani pengobatan sejak tahun 2014, dimana empat orang diantaranya meninggal. Sebanyak 32 responden yang masuk dalam kriteria inklusi dalam penelitian ini, dimana sebanyak 25 responden termasuk dalam kategori adherence dan 7 responden nonadherence.

Berdasarkan hasil penelitian yang telah dilakukan tingkat ketidakpatuhan lebih besar pada jenis kelamin laki-laki, hal ini dapat dilihat dari hasil persentasi ketidakpatuhan responden dimana jenis kelamin laki-laki memiliki total persentasi mangkir sebesar 27,27\% dan perempuan hanya $10 \%$. Hasil penelitian ini serupa dengan penelitian yang dilakukan di Timor Leste dimana jumlah mangkir dalam pengobatan jenis kelamin laki-laki lebih besar dibandingkan perempuan. Tingkat kepatuhan laki-laki lebih rendah dibandingkan perempuan, kecenderungan laki-laki lebih tinggi untuk mangkir berobat kemungkinan karena laki-laki aktivitasnya lebih tinggi dalam sehari-harinya, serta laki-laki merupakan tukang punggung keluarga yang harus bekerja.

Tabel 1. Karakteristik Responden

\begin{tabular}{ccc}
\hline \multirow{2}{*}{ Karakteristik } & \multicolumn{2}{c}{ Adherence } \\
\cline { 2 - 3 } & $\begin{array}{c}\text { Adherence }(\%) \\
\mathrm{n}=25\end{array}$ & $\begin{array}{c}\text { Non-Adherence }(\%) \\
\mathrm{n}=7\end{array}$ \\
\hline Jenis Kelamin & & $6(27,27)$ \\
Laki-laki & $16(72,73)$ & $1(10)$ \\
Perempuan & $9(90)$ & $2(20)$ \\
Usia & $8(80)$ & $3(21,43)$ \\
20-34 tahun & $11(78,57)$ & $2(25)$ \\
35-48 tahun & $6(75)$ & $5(35,71)$ \\
49-62 tahun & $9(64,23)$ & $2(11,1)$ \\
Pekerjaan & $16(88,9)$ & $4(19,05)$ \\
Bekerja & $17(80,95)$ & $3(27,3)$ \\
Tidak Bekerja & $8(72,7)$ & \\
Tempat Berobat & &
\end{tabular}




\begin{tabular}{lcc}
\hline Penyakit Penyerta & & \\
Ada & $9(81,8)$ & $2(18,18)$ \\
Tidak ada & $16(76,19)$ & $5(23,8)$ \\
Lama Pengobatan & $5(71,43)$ & $2(28,57)$ \\
$\quad$ Intensif & $20(80)$ & $5(20)$ \\
Lanjutan & & \\
\hline
\end{tabular}

*Data ditampilkan dalma bentuk n (\%)

Tabel 2. Kajian Pengobatan

\begin{tabular}{lcc}
\multicolumn{1}{c}{ Terapi } & \multicolumn{2}{c}{ Adherence } \\
\cline { 2 - 3 } & $\begin{array}{c}\text { Adherence }(\%) \\
\mathrm{n}=25\end{array}$ & $\begin{array}{c}\text { Non-Adherence }(\%) \\
\mathrm{n}=7\end{array}$ \\
\hline $\begin{array}{l}\text { Fase Intensif } \\
\text { [Z-E-Kn-Lvx-Siklo-Etio] + Vit.B } 6\end{array}$ & $5(71,43)$ & $2(28,57)$ \\
Fase Lanjutan & & $5(20)$ \\
[E-Km-LvX-Siklo-Etio-Pyr] + Vit.B & $20(80)$ & \\
*Data ditampilkan dalma bentuk $\mathrm{n}(\%)$ & &
\end{tabular}

Dari segi usia, responden yang berusia 20-34 tahun yang tidak patuh sebanyak 20\%, 35-48 tahun sebanyak 21,43\% dan 49-62 tahun sebanyak 25\%. Berdasarkan umur persentasi ketidakpatuhan responden tertinggi yaitu pada usia 49-62 tahun, angka ketidakpatuhan responden tidak terlalu signifikan sehingga dapat dilihat bahwa faktor umur bukan merupakan faktor penentu ketidakpatuhan responden dalam pengobatan karena mereka memiliki motivasi untuk hidup sehat dan selalu memperhatikan kesehatannya. Selain itu, pekerjaan yang tidak terlalu sibuk membuat responden tetap dapat menjalankan pengobatan, dimana sebagian besar responden berhenti bekerja selama menjalani pengobatan. Hal ini dapat di lihat jumlah responden yang bekerja hanya 9 dari 32 responden. Sama halnya dengan tempat berobat tidak berpengaruh secara signifikan sehingga tempat berobat bukan salah satu faktor yang berhubungan erat dalam tingkat ketidakpatuhan responden MDR-TB.

Penderita TB paru yang menderita penyakit lain, akan meningkatkan ketidakpatuhan berobat. Penyakit lain tersebut yang bersifat kronis misalnya Diabetes Mellitus, Penyakit Jantung, Hipertensi, Penyakit Saluran Napas (Asma, Pnemoni, dsb.), Rematik, Struma atau penyakit lain yang serius (Depkes, 2008). Hal ini tidak sesuai dengan jumlah ketidakpatuhan responden MDR-TB di Rumah Sakit Abdul Wahab Sjahranie dimana jumlah ketidakpatuhan sebanyak $23,8 \%$ responden tanpa penyakit penyerta dan $18,18 \%$ responden dengan penyakit penyerta. Kemungkinan ini dapat disebabkan responden memiliki kesadaran dan rasa takut akan penyakit yang diderita sehingga motivasi untuk sembuh semakin tinggi. Sedangkan lama pengobatan juga mempengaruhi ketidakpatuhan, sebanyak $28,57 \%$ responden tidak patuh pada tahap intensif dan $20 \%$ pada tahap lanjutan. Tingkat ketidakpatuhan yang lebih besar pada tahap intesif sebagian besar dipengaruhi oleh efek samping obat pada tahap intensif yaitu diantaranya adalah kapreomisin dan kanamisisn, dimana obat tersebut diberikan secara injeksi, dimana laporan dari pihak petugas kesehatan pada tahap intensif sebagian besar pengobatannya menimbulkan efek yang cukup berat diantaranya halusinasi, gangguan pendengaran, meningkatnya asam urat dan sakit kepala. Sedangkan pada tahap lanjutan, bereberapa responden merasa bosan dengan pengobatan yang cukup lama sehingga beberapa responden mangkir dalam menjalani pengobatan. 
Faktor resiko ketidakpatuhan lainnya dapat disebabkan oleh pengetahuan yang minim tentang Multi Drug Resistant Tuberculosis dan efek samping obat yang diberikan. Multi Drug Resistant Tuberculosis (MDR-TB) merupakan tuberkulosis yang resistensi terhadap dua agen anti-Tuberkulosis lini pertama yang paling poten yaiitu isoniazide (INH) dan rifampisin. MDR-TB berkembang selama pengobatan tuberkulosis ketika mendapatkan pengobatan yang tidak adekuat, dimana dapat juga disebabkan bila responden putus-putus berobat sebelum masa pengobatan selesai atau responden sering putus-putus minum obat selama menjalani pengobatan tuberkulosis. Hal ini dapat dilihat dari beberapa responden yang diberikan kuisioner mengatakan bahwa tidak mengetahui tentang MDR-TB dan pengetahuan tentang pengobatan yang cukup minim. Efek samping obat juga dapat mempengaruhi ketidakpatuhan responden dalam menjalani pengobatan. Efek samping obat juga merupakan salah satu faktor responden mangkir dalam menjalani pengobatan, dimana hasil wawancara yang dilakukakan pada beberapa responden mengeluhkan efek samping obat sebagai penyebab mangkir berobat. Sebagian besar responden MDR-TB mengeluhkan efek samping obat yang cukup kuat dan mengganggu aktivitas, dimana efek samping yang paling sering dikeluhkan oleh responden diantaranya adalah sakit kepala dan naiknya kadar asam urat, seperti halnya pada penelitian yang telah dilakukan oleh Pandit dan Choudhary dimana efek samping merupakan salah satu faktor terjadinya ketidakpatuhan dalam pengobatan.

Ketidakpatuhan responden yang menjalani pengobatan pada fase intensif sebanyak 2 orang dengan persentasi $20 \%$ dan pada fase lanjutan sebanyak 5 orang dengan persentasi $71,42 \%$. Angka tingkat ketidakpatuhan yang signifikan terjadi pada fase lanjutan dimana hal ini kemungkinan disebabkan faktor lama pengobatan yang cukup lama serta turunnya motivasi responden dalam menjalani pengobatan.

Kepatuhan terhadap pengobatan tuberkulosis begitu kompleks, fenomenanya dinamis dengan berbagai faktor yang saling berinteraksi satu sama lain, sehingga berdampak pada keputusan pemilihan perilaku. Sehingga dalam penelitian ini diharapkan didapatkan informasi yang dapat membantu mengurangi tingkat ketidakpatuhan responden MDR-TB dalam menjalani pengobatan.

\section{KESIMPULAN}

Hasil penelitian ini ditemukan angka kejadian MDR-TB di Rumah Sakit AWS Samarinda sebanyak 32 responden, dimana sebanyak 7 responden dalam tahap intensif dan 25 responden pada tahap lanjutan. Tingkat kepatuhan responden MDR-TB cukup tinggi dengan hasil $78.12 \%$.

\section{DAFTAR PUSTAKA}

World Health Organization (WHO). 2011. Global Tuberculosis Control WHO Report.

Kementerian Kesehatan Republik Indonesia. 2014. Pedoman Nasional Pengendalian

Tuberkulosis. Direktorat Jenderal Pengendalian Penyakit dan Penyehatan Lingkungan.

Departemen Kesehatan Republik Indonesia (DEPKES). 2008. Pedoman Nasional Penanggulangan Tuberkulosis. 